\title{
Organofosfatlı Pestisitlerin Pilot Ölçekli Sulak Alan Reaktörlerinde Gideriminin İncelenmesi
}

\author{
Çağrı ŞAHİN ${ }^{1,2}$, M. Ekrem KARPUZCU*2, \\ 1İzmir Yüksek Teknoloji Enstitüsü, Mühendislik Fakültesi, Çevre Mühendisliği Bölümü, Urla, İzmir \\ (ORCID: https://orcid.org/0000-0002-8886-6698) \\ ${ }^{2}$ İstanbul Teknik Üniversitesi, İnşaat Fakültesi, Çevre Mühendisliği Bölümü, Maslak, İstanbul \\ (ORCID: https://orcid.org/0000-0002-6245-9621)
}

(Alınıș / Received: 28.08.2018, Kabul / Accepted: 15.02.2019, Online Yayınlanma / Published Online: 24.04.2019)

\author{
Anahtar Kelimeler \\ Organofosfatlı pestisitler, \\ Sulak alanlar, \\ Tarımsal kirlilik, \\ Pilot ölçekli reaktör, \\ Meriç - Ergene havzası
}

\begin{abstract}
Özet: Modern tarımın yaygınlaşmasıyla birlikte dünyada pestisit kullanımı artmıştır. Birçok ülkede olduğu gibi ülkemizde de aşırı ve bilinçsizce pestisit kullanımı sonucunda su ve toprak ortamında giderek artan miktarlarda pestisit kirlenmesi görülmektedir. Meriç- Ergene Havzası'nda bulunan ve etrafında yoğun bir şekilde çeltik tarımı yapılan Meriç Deltası sulak alanları da bu kirlenmenin görüldüğü bölgelerden biridir. Bu çalışma kapsamında, Meriç Deltası sulak alanlarından numuneler alınarak organofosfatlı pestisitlerin akıbeti incelenmiştir. Sulak alanları temsil etmesi amacıyla pilot ölçekli reaktörle çalışılmış, seçilen 4 organofosfatlı pestisit (Chlorpyrifos, Dichlorvos, Fenthion, Diazinon) için biyolojik ayrışma ve adsorpsiyon deneyleri yapılmıştır. Pilot ölçekli sistemde, seçilen pestisitlerin yarı ömürleri belirlenmiş ve bitki ve sediment üzerine adsorpsiyon miktarları ölçülmüştür. Aynı zamanda pestisitlerin yeraltı suyuna sızma potansiyelleri GUS ("Groundwater Ubiquity Score" / "Yeraltı Suyunda Mevcudiyet Katsayısı") kullanılarak hesaplanmıştır. Elde edilen sonuçlar serbest yüzey akışlı yapay sulak alan sistemlerinin organofosfatlı pestisitlerin giderimindeki etkinliğini ortaya koymuştur. Bu çalışmadan elde edilen sonuçlar, organofosfatlı pestisitlerin giderimi için önerilen yapay sulak alanların tasarımı için yol gösterici niteliktedir.
\end{abstract}

\section{Investigating Fate of Organophosphate Pesticides in Pilot Scale Wetland Reactors}

\section{Keywords}

Organophosphate pesticides, Wetlands,

Agricultural pollution,

Mesocosms,

Meric- Ergene basin

\begin{abstract}
With the widespread use of modern agriculture, the use of pesticides in the world has increased. As in many countries, pesticide pollution has increasingly been observed in Turkey due to excessive and unconscious use of pesticides. Meric Delta, located in the Meric-Ergene Basin and receiving agricultural drainage from paddy fields, is one of the regions subject to pesticide pollution. In this study, samples were taken from the wetlands in Meric Delta and the fate of four organophosphate pesticides (Chlorpyrifos, Dichlorvos, Fenthion, Diazinon) was investigated in a pilot scale wetland reactor. In the pilot scale reactor set up to represent wetlands in Meric-Ergene Basin, half-lives and adsorption amounts of pesticides to plants and sediments were determined. Additionally, the potential of pesticides for leaching to the groundwater has been determined by calculating GUS ("Groundwater Ubiquity Score"). The results showed the effectiveness of free surface flow constructed wetlands in organophosphate pesticide removal. The results of this study provide key guidelines for the design of constructed wetlands for the mitigation of organophosphate pesticides.
\end{abstract}

\section{Giriş}

Modern tarımın yaygınlaşmasıyla kullanımı artan pestisitler (tarım ilaçları), bugün çevreye fazlasıyla yayılmış durumdadır. Bunlardan birçoğu tehlikeli ve zehirli olarak kabul edilen kirletici maddelerdendir
[1]. Pestisitlerin çevrede uzun süre aktif kalmaları, biyolojik birikme eğilimleri ve hedef olmayan türlere olan etkileri sağlık ve ekosistem açısından büyük tehlike oluşturmaktadır. Pestisitlerin çevreye istenmeyen biçimde yayılmasında en önemli faktörlerden biri tarımsal kaynaklı yüzey akışıdır. 
İlaçlama sonrası sulanan veya yağış alan tarımsal arazilerden kaynaklanan yüzey akışı, çözünmüş halde bulunan veya ince partiküllere adsorbe olmuş pestisitleri yüzey sularına taşımakta ve burada yaşayan balıklara ve diğer su canlılarına zarar vermektedir [2]. Aynı zamanda toprak matrisine adsorbe olmayan pestisit türlerinin yeraltı suyuna sızma eğilimleri bilinmekte olup, yeraltı suyundan yüzeysel sulara taşınımı ve sucul ekosistem üzerinde etkileri değerlendirilmektedir [3].

Zirai mücadelede dünya çapında geniş bir kullanıma sahip olan organofosfatlı pestisitler (OP), ülkemizde de yaygın olarak kullanılmaktadır [4,5]. Türkiye'de senelik 30.000 tonun üzerinde pestisit kullanılmaktadır. Kullanılan pestisitlerin \%47'sini böcek ilaçları (insektisitler) oluşturmaktadır [6]. Günümüzde kullanılan insektisit grubu üyelerinin büyük çoğunluğu organofosfatlı bileşiklerdir [5]. OP'lerin çoğu biyolojik ayrışma eğilimi yüksek olan bileşiklerdir. Bu nedenle OP'ler, DDT gibi organoklorlu pestisitlerin yerini almışlardır. Ancak, özelikle memeliler üzerinde oluşturdukları yüksek akut toksisite nedeniyle kullanımları tartışılmaktadır [7]. Türkiye'de pestisit kaynaklı zehirlenmelerin yaklaşık \%21'inin, Amerika Birleşik Devletleri'nde (ABD) ise \%33'ünün kaynağı organofosfatlı pestisitlerdir [8]. Bu veriler göz önüne alındığında, organofosfatlı pestisitlerin çevreye yayılmasının önlenmesi ve etkin bir biçimde kontrolünün ve gideriminin sağlanması gerektiği açıktır.

$\mathrm{Bu}$ projede çalışma alanı olarak seçilen Meriç-Ergene Havzası, Türkiye'nin önemli tarım bölgelerinden biridir. Türkiye'deki pirinç üretiminin \%54'ü bu bölgeden karşılanmaktadır [9]. Meriç Nehri'nin Ege Denizi'ne döküldüğü yerde bulunan Meriç Deltası sulak alanı, uluslararası öneme sahip bir sulak alan ekosistemidir. Sulak alan sınırları içerisinde bulunan Gala Gölü, Pamuklu Göl ve çevresindeki 2369 ha genişliğindeki alan, 1991 yılında "Tabiatı Koruma Alanı" ilan edilerek "Milli Parklar Kanunu” kapsamına girmiştir. Sulak alan çevresinde yoğun bir şekilde çeltik tarımı yapılmaktadır. Tarım arazilerinden gelen sulama suları içerisinde bulunan yüksek miktardaki gübre ve pestisitler, Meriç Nehri'ne ve diğer su kaynaklarına ulaşmakta, havzadaki ekosistemi ve su kalitesini tehdit etmektedir. Öterler (2009) tarafından Gala Gölü'nde yapılan bir çalışmada, su fazında toksisite değerlerini aşan miktarlarda organofosfatlı pestisitlere rastlanmıştır. Bu pestisitlerin hidrofobik yapıları göz önüne alındığında, su fazında ölçülen konsantrasyonlardan çok daha fazlasının sediment fazında bulunması beklenmektedir. $\mathrm{Bu}$ durum, havzadaki su kaynaklarının içinde bulunduğu tehlikenin boyutlarını ortaya koymaktadır.

Tarımsal faaliyetler sonucu çevreye yayılan kirleticiler, yüzey akışları ile yerüstü sularına doğrudan karışmaktadır. Bu durumu engellemek ve etkili bir pestisit giderimi sağlamak için doğal ve yapay sulak alanlar, özelikle Avrupa ve Amerika'da yaygın olarak kullanılmaya başlanmıştır [10-18]. Sulak alanlar, inşaat maliyetinin düşük olması ve işletilmesinde kalifiye teknik eleman gerektirmemesi nedeniyle, arazinin müsait olduğu yerlerde kirletici gideriminde büyük avantaj sağlamaktadırlar $[19,20]$. Sulak alanlarda OP'lerin giderimi, bitki ve sediment yüzeyine adsorpsiyon, biyolojik ve kimyasal ayrışma süreçleriyle sağlanır. Bu mekanizmalardan hangisinin daha etkin rol oynayacağ söz konusu pestisitin fiziksel ve kimyasal özelliklerine bağlıdır.

Orman ve Su İşleri Bakanlığı tarafından 2013 yılında, "Bitki Koruma Ürünlerinin Kullanımı Neticesinde Meydana Gelen Su Kirliliğinin Tespiti ve Madde veya Madde Grubu Bazında Çevresel Kalite Standartlarının Belirlenmesi Projesi (BİKOP) Çalışma Grubu" kurulmuştur. $\mathrm{Bu}$ grubun çalışmaları ışı̆̆ında, ülkemizde geçmiş yıllarda kullanılan ve kullanılmaya devam eden pestisitler belirlenerek, BİKOP aktif madde karşılaştırma listesi oluşturulmuştur. Bu listede, pestisitlerin yarı ömürleri (kalıcılığı) ve biyobirikim özellikleri göz önüne alınarak önceliklendirme yapılmış, bunun sonucunda "Öncelikli Pestisitler Listesi" adı altında ek bir liste elde edilmiştir. Bu çalışma kapsamında, listede belirtilen pestisitler göz önüne alınarak kullanımı yaygın olan dört organofosfatlı pestisit seçilmiştir. Seçilen organofosfatlı pestisitler ve kimyasal formülleri Tablo 1'de verilmiştir.

Tablo 1. Çalışma kapsamında incelenen organofosfatlı pestisitler.

Pestisit Adı Yapısal Formülü

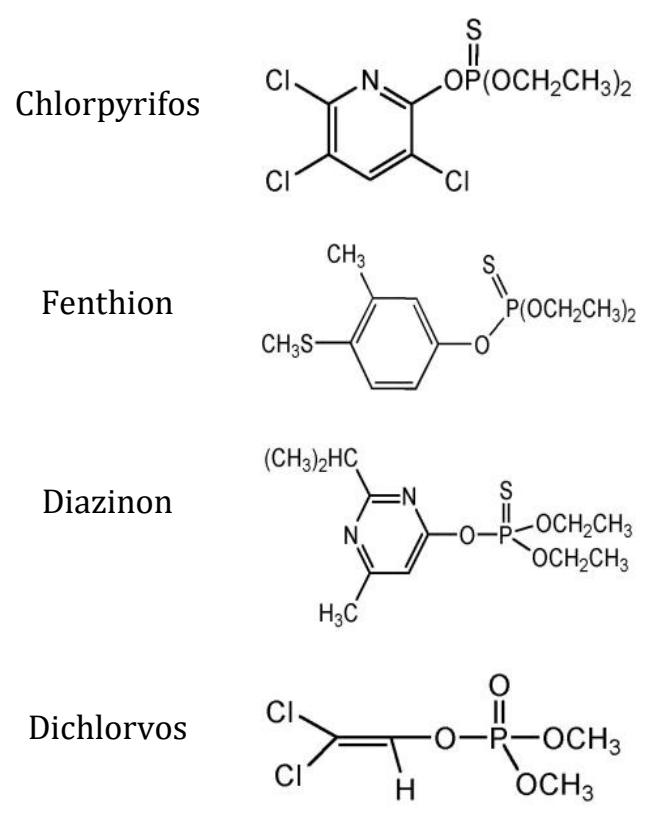

Sulak alanlar için kirleticilerin akıbetinin belirlenmesinde pilot ölçekli (mezokozmos) çalışmalar yaygın olarak kullanılmaktadır [21]. Bu tarz çalışmalar yapay sulak alan modelleri için alt yapı oluşturulmasına yardımcı olmaktadır [22]. Pilot ölçekli çalışmalarda sediment içeriği, akış tipi, temas 
yüzey alanı ve su derinliği gibi parametreler değişkenlik göstermektedir. Bu durum, pilot ölçekli çalışmaların birbirleriyle direk olarak kıyaslanmasını engellemektedir [3]. Farklı pestisit tipleri ve farklı koşullar için farklı tasarım kriterleri mevcuttur [3, 2125]. Pestisit giderim verimini arttırmak için bitkilendirilmiş şerit destekli pilot ölçekli çalışmalar da kullanılmaktadır. Farklı bitki türlerinin kullanıldığı sistemler OP'lerin giderimi için önemli sonuçlar vermektedir [11, 26-28]. Son yıllarda kullanımı fazla olan OP'ler için pilot ölçekli sistemlerde aerobik şartlar altında 1 ile 48 gün arasında değişen yarı ömürler tespit edilmiştir [1, 29-33].

$\mathrm{Bu}$ çalışmanın amacı, (1) ülkemizde kullanımı yaygınlaşmaya başlayan yapay sulak alanların tarım arazilerinden gelen drenaj sularında bulunan organofosfatlı pestisitlerin gideriminde ne derece etkili olduğunun belirlenmesi, (2) drenaj kanallarına yerleştirilen bitkilendirilmiş şerit gibi en iyi uygulama yöntemlerinin, pestisitlerin adsorpsiyon özellikleri göz önüne alınarak giderim verimine olan katkılarının incelenmesi, (3) organofosfatlı pestisitlerin giderimi için önerilen yapay sulak alanların tasarımında yol gösterici niteliğe sahip birtakım kriterlerin ortaya konmasıdır.

\section{Materyal ve Metot}

\section{1. Çalışma alanı}

Saha çalışması kapsamında Meriç-Ergene Havzası'nda yer alan Gala Gölü'nden (koordinatları; 40.769045, 26.167406 ) Eylül 2015 ve Temmuz 2016 tarihleri arasında iki kere olmak üzere sediment numuneleri alınmıştır. Gala Gölü, çevresinde yoğun çeltik tarımı yapılan ve daha önce yapılan çalışmalarda pestisit konsantrasyonu tespit edilen $[9,34]$ bir sulak alandır.

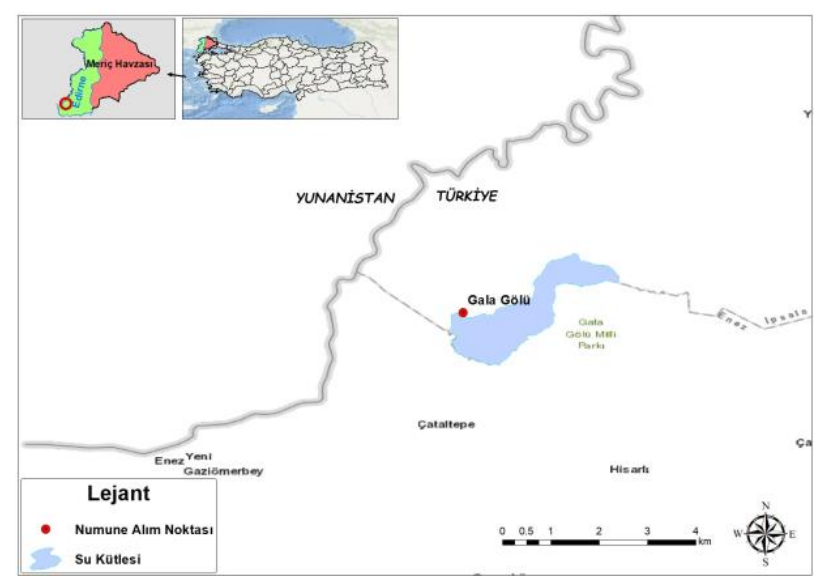

Şekil 1. Çalışma alanı ve numune alma noktaları

Çalışma sahasından sediment numuneleri 5L hacimli plastik kavanozlara paslanmaz çelik kürek yardımıyla alınmıştır. Kavanozların içinde yaklaşık olarak 10 kg ağırlı̆̆ında sediment numuneleri bulunmaktadır. Numuneler alınmadan önce plastik kavanozlar biyolojik olarak ayrışabilen özel bir deterjanla (ALCANOX, Inc.) ile üç sefer yıkanmış ve örneklerin alındığı kürek için de aynı işlemler yapılmıştır. Sediment numuneleri, içinde buz kalıpları bulunan soğutucu kutuya alınıp aynı gün pilot ölçekli reaktörün bulunduğu laboratuvara götürülmüştür.

\subsection{Kullanılan kimyasallar}

Deneylerde kullanılan pestisitler, (Sigma-Aldrich, ABD) şirketinden temin edilmiştir. Fenthion (FTH), Diazinon (DIA) ve Dichlorvos (DDVP) sıvı halde ve 250 mg miktarda, Chlorpyrifos (CPF) ise katı toz halde 100 mg miktarda temin edilmiştir. Deneylerde kullanılan bu dört pestisit için Merck, Almanya şirketinden temin edilen \%99,8 saflık yüzdesine sahip ve gaz kromotografisi standartlarında olan n-hekzan solventi kullanılarak 1g/L'lik stok çözeltiler hazırlanmıştır. Hazırlanan stok çözeltiler, $4^{\circ} \mathrm{C}$ sıcaklığa sahip karanlık bir dolapta saklanmıştır. HPLC cihazında yapılan analizlerde mobil faz içeriğinde bulunan asetonitril solventi (Merck, Almanya) şirketinden temin edilmiştir. \%99,9 saflıkta olup HPLC standartlarındadır.

\subsection{Deneysel yöntemler ve kullanılan cihazlar}

Seçilen dört pestisitin analiz ve kalibrasyonu, Shimadzu marka 20A tipi HPLC cihazı ile yapılmıștır. Analizler için Inertsil marka ODS-3V tipi $5 \mu \mathrm{m}$ 4,6 x 250 mm boyutunda bir kolon kullanılmıştır. Mobil faz için asetonitril-su karışımı kullanılan analizlerde, mobil faz oranları analizi yapılan pestisitin polarlık derecesine göre ayarlanmıştır. Analizlerde kullanılan mobil faz (asetonitril-su) oranları; FTH ve DIA için 7:3, DDVP için 3:2 ve CPF için 4:1 olarak belirlenmiştir. Akış süresi $1,4 \mathrm{ml} / \mathrm{dk}$., enjeksiyon hacmi $20 \mu \mathrm{L}$ ve kolon sicaklığı ise $40^{\circ} \mathrm{C}^{\prime}$ dir. 15 dakikalık analiz süresinde, $5 \mathrm{mg} / \mathrm{L}, 1 \mathrm{mg} / \mathrm{L}, 0.5 \mathrm{mg} / \mathrm{L}, 0.1 \mathrm{mg} / \mathrm{L}, 0.05$ $\mathrm{mg} / \mathrm{L}$ ve $0.01 \mathrm{mg} / \mathrm{L}$ konsantrasyonuna sahip pestisit çözeltileri için kalibrasyon eğrileri oluşturulmuştur. CPF, DDVP, FTH ve DIA için alıkonma süresi sırasıyla $8,16,7,51,7,55$ ve 8,87 dakika olarak tespit edilmiştir. HPLC analizlerinde UV detektör ile 190-800 nm bandında tarama yapılmış ve CPF, DDVP, FTH ve DIA için maksimum dalga boyları sırasıyla $225 \mathrm{~nm}, 200$ $\mathrm{nm}, 254 \mathrm{~nm}$ ve $246 \mathrm{~nm}$ olarak bulunmuştur.

\subsection{Pilot ölçekli reaktörün kurulumu}

Yapılan çalışmalarda sulak alanları en iyi şekilde temsil etmesi amaciyla pilot ölçekli reaktör sistem kullanılmıştır. Yaklaşık 105L hacime sahip iki reaktörden oluşan sistemde, her reaktör $(70 \mathrm{~cm}$ x 50 $\mathrm{cm}$ x $30 \mathrm{~cm}$, Boy x Yükseklik x En) boyutuna sahiptir. Bitişik yerleștirilen iki reaktöre yükleme ișlemi pompa sistemleriyle yapılırken, reaktörlerin tahliyesi vana yardımıyla yapılmaktadır. 4 adet $6500 \mathrm{~K}$ led ışıklandırma sistemi reaktörlerin $50 \mathrm{~cm}$ üstünde olacak șekilde yerleștirilmiş ve bitkilerin günlük metabolik faaliyetlerini yerine getirmeleri amaçlanmıştır. Reaktörler, kesikli reaktör olarak işletilmeye uygun olacak şekilde tasarlanmıştır. 


\subsection{Biyolojik Ayrışma Deneyleri}

Biyolojik ayrışma deneyleri için pilot ölçekli sistem kesikli reaktör olarak kullanılmıştır. Deneylerde kullanılan sediment numuneleri Gala Gölü'nü besleyen drenaj kanallarından alınmış ve reaktörlere $20 \mathrm{~cm}$ yüksekliğinde olacak şekilde doldurulmuștur. Ekimi yapılan bitkiler ise, Meriç Delta'sında nadir olarak bulunan narin sulak alan saz bitkisi Vallisneria Spiralis'dir [35]. Bitkilerin ve alınan sediment numunelerinde bulunan mikroorganizmaların yaşamsal faaliyetlerini gerçekleştirmek ve büyümelerini sağlamak amacıyla hazırlanan besin maddeleri ile birlikte çalışılacak pestisitleri içeren 20 L hacmindeki çözelti, reaktörde bulunan sediment katmanı üzerine YT600-1J-endüstriyel tip peristaltik pompa (Longer Precision Pump, İngiltere) yardımıyla doldurulmuştur. Pilot ölçekli sistemde kullanılan besleme çözeltisi, Gala Gölü su kalitesi parametrelerine göre düzenlenmiş olup, yapılan literatür çalışmalarına göre dört mevsim boyunca gözlenen ve ortalaması alınan değerleri yansıtmaktadır. Buna göre besleme çözeltisi, $15 \mathrm{~L}$ hacminde saf suda $0,005 \mathrm{~g} \mathrm{KH}_{2} \mathrm{PO}_{4}, 0,1 \mathrm{~g}\left(\mathrm{NH}_{4}\right)_{2} \mathrm{SO}_{4}$, $0,005 \mathrm{~g} \mathrm{KNO}_{3}, 2 \mathrm{~g} \mathrm{NaCl}, 0,25 \mathrm{~g} \mathrm{MgSO}_{4} .7 \mathrm{H}_{2} \mathrm{O}, 2.25 \mathrm{~g}$ $\mathrm{CaCl}_{3} \cdot 2 \mathrm{H}_{2} \mathrm{O}$ bileşikleri çözülerek hazırlanmıştır. Çözeltinin $\mathrm{pH}$ değeri $\mathrm{NaOH}$ ve MOPS çözeltisi ile 8.3'e sabitlenmiştir. Konsantrasyonlar teorik olarak hesaplanmıştır. Fosfat ve nitrat konsantrasyonlarının ölçümleri nitrat ve fosfat kiti (Hanna Instrument, ABD) ile yapılmıştır. $\mathrm{Bu}$ ölçümlerde, $\mathrm{NO}_{3}{ }^{-}$konsantrasyonu $2,26 \mathrm{mg} / \mathrm{L}$ ve $\mathrm{P}_{-} \mathrm{PO}_{4}{ }^{3-}$ konsantrasyonu $0,2 \mathrm{mg} / \mathrm{L}$ olarak belirllenmiş ve Gala Gölü su kalitesi parametrelerine uygunluğu teyit edilmiştir. Hanna Instrument (ABD) şirketinden temin edilen iletkenlik cihazı ile pilot ölçekli reaktördeki sulu çözeltinin iletkenliği 2,01 $\mu$ mhocm$^{-1}$ olarak ölçülmüştür.

Pestisit türleri için başlangıç konsantrasyonu $(20 \mathrm{~L}$ hazırlanan çözeltide); DIA için $250 \mu \mathrm{g} / \mathrm{L}$ ve diğer üç pestisit için ise $200 \mu \mathrm{g} / \mathrm{L}$ olarak belirlenmiştir. Reaktör tabanını dolduran sediment ile ekimi yapılan bitkiler 24 saat boyunca hazırlanan çözelti ile temas ettirilmiştir. 24 saat sonunda sistemde bulunan çözelti tahliye edilmiş, 1 saat sonrasinda pompa sistemiyle tekrar dolum yapılmıştır. Pestisitlerin HPLC cihazında tespit limitleri; CPF ve FTH için $1 \mu \mathrm{g} / \mathrm{L}$, DDVP için 20 $\mu \mathrm{g} / \mathrm{L}$ ve DIA için $40 \mu \mathrm{g} / \mathrm{L}$ olarak ölçülmüştür. Bitki ve sediment numunelerinin analizi için reaktörden $0 ., 1$. , 3. , 5. , 7., 10. ve 15. gün örnekleri alınmıștır. Pestisit konsantrasyonlarının tespit limitlerinin altına düşmesinden sonra analizler sonlandırılmıştır. Alınan örneklerden üçlü tekrarlı (triplicate) ölçümler yapılmıştır. Deneyler sediment ve su numuneleri için sıvı-sıvı ekstraksiyonları kullanılarak yapılmıştır [36, 37]. Islak sediment numuneleri ve su numuneleri 10 ml'lik deney tüplerine alınarak 2 ml'lik solvent ile ekstraksiyon yapılmıștır. DDVP pestisitinin polar yapısı göz önüne alınarak, DDVP için ekstraksiyon işlemi etilasetat solventi, diğer üç pestisit için ekstraksiyon işlemleri ise n-hekzan solventi kullanılarak 2 saat boyunca dönel karıștırıcı yardımıyla yapılmıştır. Ekstraksiyon işlemi sonrasında üst fazdan alınan $1 \mathrm{ml}$ hacmindeki solvent kuru hava ile uçurulmuştur. Distile su ile süspanse edilen çökelti, 1,5 ml hacmindeki viallere alınarak analiz edilmiştir. Böylece, başlangıç anından itibaren azalan pestisit konsantrasyonları ölçülerek her bir pestisit için biyolojik ayrışma hızı eğrileri elde edilmiştir.

\subsection{Adsorpsiyon Deneyleri}

Organofosfatlı pestisitlerin reaktördeki sedimentlere ve bitkilere adsorpsiyonunu belirlemek amaciyla, adsorpsiyon deneyleri yapılmıştır. Bitki ve sediment yüzeyine adsorpsiyon yüzdesinin araştırıldığı deneylerde, $500 \mu \mathrm{g} / \mathrm{L}$ konsantrasyona sahip pestisit çözeltileri kullanılmıştır. Sediment ve bitki numuneleri kuru ağırlığı 0,3 g tartılarak $25 \mathrm{ml}$ hacme sahip pestisit çözeltileriyle deney tüpüne alınmıştır. 16 saat boyunca karanlık bir oda içerisinde tam karışımlı çalkalayıcı ile numune yüzeylerine temas sağlanmıștır. Eş zamanlı olarak, içerisinde sediment ve bitki ihtiva etmeyen $25 \mathrm{ml}$ pestisit çözeltilerinin bulunduğu deney tüpleri aynı işlemlere maruz bırakılarak kontrol deneyleri gerçekleștirilmiştir. Kontrol deneylerindeki sonuçlar \%100 olarak kabul edilip, sediment ve bitki yüzeylerine adsorbe olan pestisitlerin yüzdesel miktarları kontrol reaktörlerine göre belirlenmiștir. Deneyler her bir adsorpsiyon deneyi için üçer kere tekrar edilerek ortama değerler esas alınmıştır. 16 saat sonunda çalkalayıcıdan alınan numuneler santrifüj edilerek üst fazlarından alınan örneklerinin analizi HPLC cihazında yapılmıștır. Üst fazdan alınan örneklerin yanı sıra, bitkiler için havanda dövülerek ilgili solvent ile ekstrakte edilen çözeltiler ve sediment numunesi için solvent ile ekstrakte edilen çözeltiler sonuçların kontrolü amacıyla analiz edilmiştir.

\section{7. İstatistiksel Analiz}

Bütün istatistiksel analizler için SPSS v.24 (IBM, Armonk, New York, ABD) yazilımı kullanılmıştır. Deneyler üçlü tekrar yapılarak analize alınmıştır. Çıkan sonuçlar için ortalamaların standart hata değerleri aşağıdaki (Denklem 1) ile hesaplanmıştır. Denklem ile üçlü tekrar yapılan deney sonuçları için oluşturulan standart ortalama değerleri her bir nokta için hata çubukları ile gösterilmiştir. Biyolojik ayrışma deneyleri sonuçları birinci dereceden bozunma eğrilerine fit edilmiş ve belirleme katsayısı $R^{2}$ değerleri 0.88 ile 0.98 arasında değişkenlik göstermiştir.

$$
\sigma=\sqrt{\frac{\sum_{i=1}^{N}\left(x_{i}-x\right)^{2}}{N}}
$$

\section{Bulgular}

Seçilen pestisitlerin kesikli işletilen üstü açık pilot ölçekli reaktörde biyolojik ayrışma süreleri incelenmiştir. 


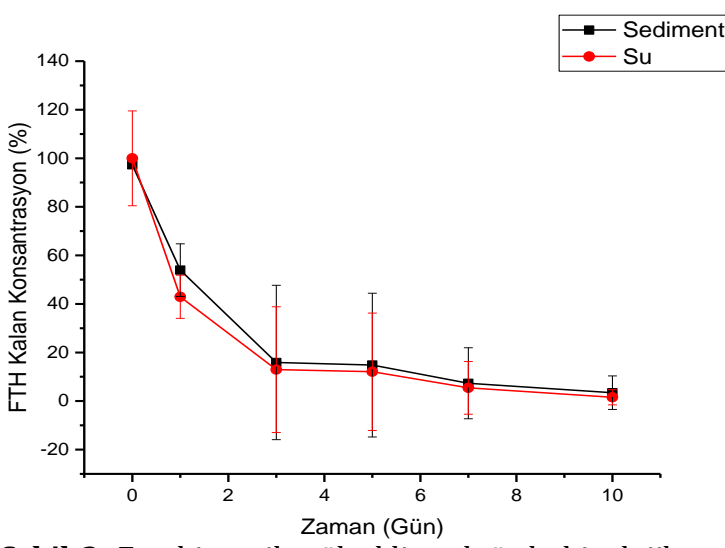

Şekil 2. Fenthion pilot ölçekli reaktörde biyolojik ayrışma eğrisi

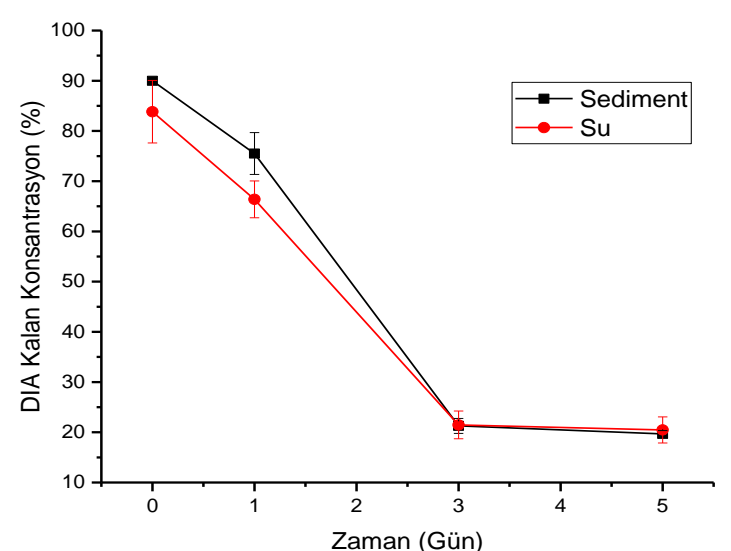

Şekil 3. Diazinon pilot ölçekli reaktörde biyolojik ayrışma eğrisi

Bulunan sonuçlar en iyi yönetim uygulaması olarak görülen sulak alanların pestisit giderimindeki Bulunan sonuçlar en iyi yönetim uygulaması olarak görülen sulak alanların pestisit giderimindeki potansiyel performansını görmek açısından aydınlatıcı olmuştur.

Pestisitlerin, su ve sediment fazlarındaki biyolojik ayrışma hızı eğrileri Şekil 2-5'de görülmektedir. Bu eğrilerden birinci derece bozunma reaksiyonu kabulü ile elde edilen ayrışma hızı katsayıları ise Tablo 2'de verilmiștir.

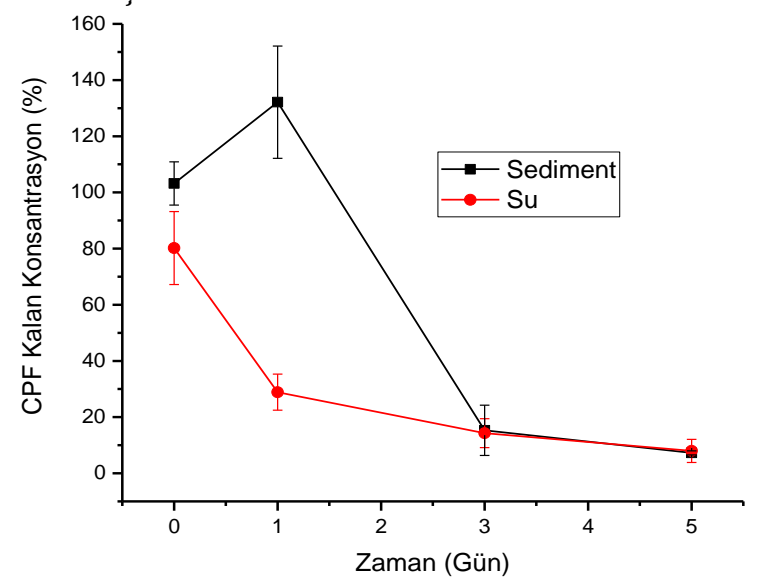

Şekil 4. Chlorpyrifos pilot ölçekli reaktörde biyolojik ayrışma eğrisi
Pestisitlerin topraktan yeraltı sularına sıma potansiyelinin bilinmesi, yeraltı suyu kalitesini korumak ve gerekli tedbirleri zamanında alabilmek açısından önemlidir. Pestisitlerin topraktan yeraltı sularına sızmasını ifade eden değer GUS ("Groundwater Ubiquity Score" veya "Yeraltı Suyunda Mevcudiyet Katsayısı") ile tanımlanmıștır [38]. Bu katsayı, $K_{o c}$ değerine ve pestisitin yarlanma ömrüne bağlı olarak hesaplanabilir (Denklem 2).

$$
G U S=\log t_{1 / 2} x\left(4-\log K_{o c}\right)
$$

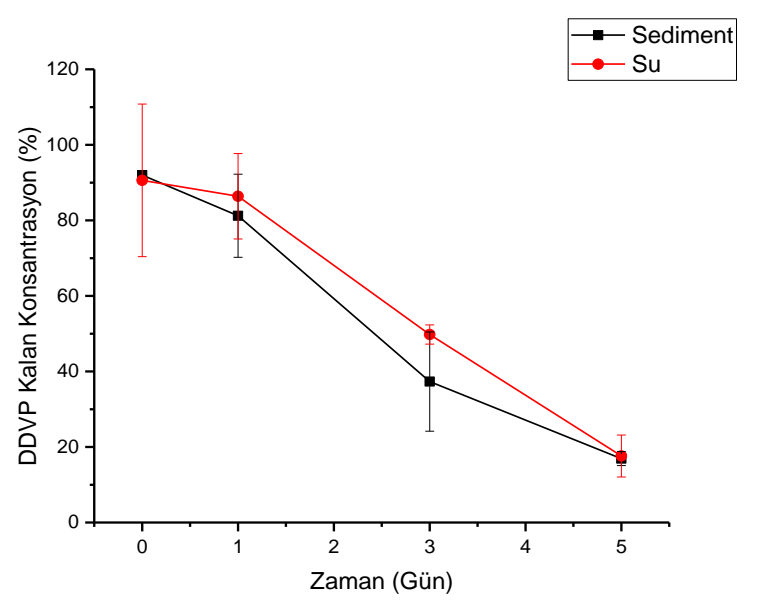

Şekil 5. Dichlorvos pilot ölçekli reaktörde biyolojik ayrışma eğrisi

$\mathrm{K}_{\mathrm{oc}}$ değeri organik maddelerin toprak yüzeyine adsorpsiyon eğilimlerini ifade eden bir parametredir. $\mathrm{Bu}$ parametrenin $1000 \mathrm{~L} / \mathrm{kg}$ üzerindeki değerleri için maddenin toprak veya sediment yüzeyine adsorplanma eğiliminin yüksek olduğu, 300-500 L/kg aralığındaki değerleri için ise düşük adsorplanma eğiliminde olduğu bilinmektedir. Sediment veya toprak yüzeyine adsorpsiyon direk olarak toprağın veya sedimentin ihtiva ettiği organik madde ile doğru orantılı olduğundan, partisyon katsayısı $K_{d}$ yerine organik içeriğe göre normalize edilmiş $\mathrm{K}_{\mathrm{oc}}$ dağılım katsayısı daha gerçekçi sonuçlar vermektedir. $\mathrm{K}_{\mathrm{oc}}$ katsayısı, hidrofobik karakteri gösteren oktanol-su partisyon katsayısı $\mathrm{K}_{\mathrm{ow}}$ ile ilişkilendirilebilir (Denklem $3)$.

$$
\log K_{o c}=a \cdot \log K_{o w}+b
$$

Literatürde organofosfatlı pestisitler için a ve b değerleri sırasıyla 0,52 ve 0,7 olarak verilmiştir [39, 40]. $\mathrm{Bu}$ değerlere göre hesaplanan $\mathrm{K}_{\mathrm{oc}}$ değerleri Tablo 3'de verilmiştir.

Pestisitlerin topraktan yeraltı sularına sızma eğilimlerinin, hesaplanan GUS değerinin 2,8 ve üzerinde olmasıyla yüksek, 1,8 değerinin altında olmasıyla düşük ve 1,8 ile 2,8 arasında olmasıyla orta seviyede (marjinal sızma eğilimi) olduğu belirtilmiştir. Tablo 3'deki $\mathrm{K}_{\text {oc }}$ değerleriyle, pilot ölçekli reaktördeki deneylerden elde edilen yarllanma ömrü süreleri kullanılarak Denklem 2'ye göre hesaplanan GUS değerleri Tablo 4'de verilmiştir. 
Tablo 2. Pilot ölçekli reaktörde su ve sediment fazında pestisitlerin biyolojik ayrışma hızı katsayıları ve yarılanma ömürleri

\begin{tabular}{ccccc}
\hline Pestisit & $\begin{array}{c}\text { Su fazı k değeri } \\
\left(\text { gün }^{-1} \text { ) }\right.\end{array}$ & $\begin{array}{c}\text { Sediment fazı k değeri } \\
\text { (gün-1) }^{-1}\end{array}$ & $\begin{array}{c}\text { Su fazı yarlanma ömrü } \\
\text { (gün) }\end{array}$ & $\begin{array}{c}\text { Sediment fazı yarılanma } \\
\text { ömrü (gün) }\end{array}$ \\
Fenthion & 0,36 & 0,262 & 1,94 & 2,64 \\
Chlorpyrifos & 0,593 & 0,518 & 1,16 & 1,33 \\
Diazinon & 0,288 & 0,309 & 2,4 & 2,24 \\
Dichlorvos & 0,349 & 0,394 & 1,98 & 1,75 \\
\hline
\end{tabular}

Tablo 3.Literatürden alınan $\mathrm{K}_{\mathrm{ow}}$ değerleri ve hesaplanan $\mathrm{K}_{\mathrm{oc}}$ değerleri [41-44].

\begin{tabular}{|c|c|c|}
\hline Pestisit & $\begin{array}{c}\text { log kow } \\
(\mathrm{L} / \mathrm{kg})\end{array}$ & $\begin{array}{c}\text { Hesaplanan Koc } \\
\text { değeri }(\mathrm{L} / \mathrm{kg})\end{array}$ \\
\hline Fenthion & 4,09 & 671 \\
\hline Chlorpyrifos & 5,27 & 2756 \\
\hline Diazinon & 3,81 & 480 \\
\hline Dichlorvos & 1,16 & 20 \\
\hline
\end{tabular}

Tablo 4. Pestisitlerin GUS değerleri

\begin{tabular}{|l|l|l|l|}
\hline Pestisit & $\begin{array}{l}\text { Yarılanma } \\
\text { ömrü } \\
\text { (gün) }\end{array}$ & $\begin{array}{l}\text { Hesaplanan } \\
\text { Koc değeri } \\
\text { (L/kg) }\end{array}$ & $\begin{array}{l}\text { GUS } \\
\text { değeri }\end{array}$ \\
\hline Fenthion & 2,64 & 671 & 0,49 \\
\hline Chlorpyrifos & 1,33 & 2756 & 0,07 \\
\hline Diazinon & 2,24 & 480 & 0,46 \\
\hline Dichlorvos & 1,75 & 20 & 0,65 \\
\hline
\end{tabular}

Pestisitler için hesaplanan GUS değerleri incelendiğinde, Chlorpyrifos, Fenthion, Diazinon ve Dichlorvos için bu değerlerin 1,8 değerinden düşük olduğu görülmektedir. 1,8'den düşük değere sahip olan dört pestisit için yeraltı sularına sızma eğilimlerinin ve topraktaki hareketlerinin (mobilitelerinin) düşük olduğu sonucuna varılabilir.

Tablo 5. Sediment ve bitki yüzeyine adsorplanan pestisit miktarları

\begin{tabular}{|l|l|l|}
\hline & \multicolumn{1}{|c|}{$\begin{array}{c}\text { Sediment } \\
\text { yüzeyi }\end{array}$} & \multicolumn{1}{c|}{$\begin{array}{c}\text { Bitki } \\
\text { yüzeyi }\end{array}$} \\
\hline Fenthion & $10,7 \mu \mathrm{g} / \mathrm{g}$ & $20,6 \mu \mathrm{g} / \mathrm{g}$ \\
\hline Chlorpyrifos & $30,7 \mu \mathrm{g} / \mathrm{g}$ & $10,9 \mu \mathrm{g} / \mathrm{g}$ \\
\hline Diazinon & $3,5 \mu \mathrm{g} / \mathrm{g}$ & $9,9 \mu \mathrm{g} / \mathrm{g}$ \\
\hline Dichlorvos & $11,0 \mu \mathrm{g} / \mathrm{g}$ & $3,8 \mu \mathrm{g} / \mathrm{g}$ \\
\hline
\end{tabular}

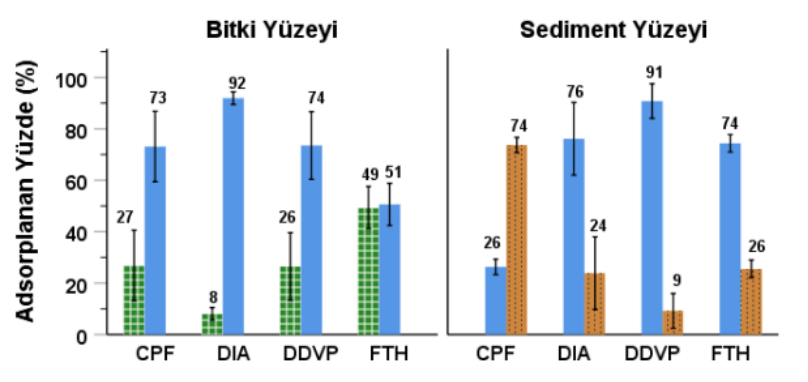

\section{曲 Bitki Yüzeyine Adsorplanma Yüzdesi Sulu Çözeltide Bulunan Yüzde \\ Sediment Yüzeyine Adsorplanma Yüzdesi}

Şekil 6. Sediment ve bitki yüzeyine adsorplanan yüzde

Pestisitlerin sulak alandaki davranışının anlaşılabilmesi için, sediment ve bitki yüzeylerine adsorpsiyon eğilimlerinin belirlenmesi önemlidir. Adsorpsiyon deneyleri sonunda elde edilen sonuçlar pestisitlerin bitki ve sediment yüzeylerine adsorpsiyonu hakkında bilgi vermesi amacıyla değerlendirilmiştir. Deneylerden elde edilen sonuçlar Şekil 6 ve Tablo 5'de görülmektedir. Elde edilen sonuçlara göre, sediment yüzeyine en fazla adsorpsiyon eğilimi olan pestisit CPF iken, bitki yüzeyine adsorpsiyon eğilimi en fazla olan pestisit ise FTH'dır

\section{Tartışma ve Sonuç}

Pilot ölçekli sulak alan reaktöründe yapılan biyolojik ayrışma deneyleri, serbest yüzey akışlı bir sistemin aerobik şartlar altında organofosfatlı pestisitlerin gideriminde ne derece etkili olabileceğini göstermiştir. Kesikli işletilen reaktörde, bitki ve sediment yüzeyine adsorbe olan pestisitlerin hava ile teması ve sediment yüzeyinin havalanması sağlanmıştır. Pestisit konsantrasyonuna sahip sulu çözeltinin 24 saat aralıklarla boşaltılması ile kesikli işletilen reaktörde sediment yüzeyinin adsorpsiyon kapasitesi maksimum düzeye çıkarılmıştır. Bitki kökleri ve sediment yüzeyine adsorplanan pestisitler, biyolojik aktivite sonucu ayrışmaya uğramışlardır. Laboratuvar ölçekli çalışmalar ile kıyaslandığında [4548], kesikli işletilen ve aerobik şartlara sahip olan pilot ölçekli sulak alan reaktörünün daha hızlı ayrışmaya olanak sağladığı görülmüştür. Bu durum, bitki kökleri ve geniş sediment yüzeyinde bulunan biotanın biyolojik ayrışmanın hızlanmasına katkı sağlaması ile açıklanabilir. Yapay sulak alan sistemlerinin, işletme koşullarının uygulanan pestisitlerin yapısına göre değiştirilebilmesine olanak sağlaması nedeniyle en iyi yönetim uygulaması olarak kullanılabileceği öngörülmüştür.

Yapay sulak alan sistem seçimi ve tasarımında önemli rol oynayan bir parametre olan pestisitlerin bitki yüzeylerine adsorpsiyon yüzdeleri yine bu çalışma kapsamında ortaya konmuştur. Pestisitlerin bitki yüzeyi ile sediment yüzeyine adsorpsiyon değerleri karşılaştırıldığında, FTH ve DIA için daha yüksek oranda bitki yüzeyine adsorpsiyon eğilimleri görülmüştür. Tarım ilacı olarak FTH ve DIA pestisitlerinin uygulandığı bir tarım alanında, tarımsal drenaj kanalları çıkışına kurulacak yapay sulak alan sisteminin yoğun bir şekilde bitkilendirilmiş olması, bitki yüzeylerine adsorplanma eğiliminde olan bu pestisitlerin giderim verimini arttıracaktır. Yapay sulak alanlarda bitki yoğunluğu genelde $0,1-4$ bitki $/ \mathrm{m}^{2}$ olarak değişmekte olup, yoğun bitkili sistemlerde yüzeyin yaklaşık \%80'i bitki ile kaplıdır. FTH ve DIA için tasarlanacak sistemlerde yoğun bir 
şekilde bitkilendirilmiş yapay sulak alan sistemleri önerilmektedir. CPF pestisiti için ise \% 75 üzerinde sediment yüzeyine adsorpsiyonu gerçekleşmiştir. Bu durum göz önüne alınarak, CPF için tasarlanacak yapay sulak alanlar için aralıklarla havalandırılan geniş sediment yüzeyine sahip sistemlerin seçilmesi öngörülmüştür. DDVP için yapılan biyolojik ayrışma deneylerinde bu pestisitin hidroliz hızının yüksek olduğu görülmüștür. DDVP gideriminde kullanılacak yapay sulak alanların serbest yüzey akışına ve havalandırılmış açık su yüzeyine sahip olması önerilmektedir. Bu şekildeki bir tasarım, DDVP pestisitinin hidrolize uğrayarak daha kolay parçalanmasına olanak sağlayacaktır. Bu çalışmadan elde edilen sonuçlar, organofosfatlı pestisitlerin giderimi için önerilen yapay sulak alanların tasarımı için yol gösterici niteliktedir.

Yapay sulak alanlarda giderim verimi hesaplanırken alansal giriş yükleri ve alansal giderim katsayıları üzerinden hesaplama yapıldığı için, yüzey alanının artması pestisit giderim verimini arttıracaktır. Yapay sulak alanlar tasarlanırken, hidrolik bekletme süreleri, giderilmesi istenen pestisitin yarı ömrüne bağlı olarak seçilir. Daha önce yapılan çalışmalarda aerobik şartlar altında organofosfatlı pestisitlerin biyolojik ayrışma hızlarının anaerobik şartlara göre daha yüksek olduğu belirtilmiş olup $[1,46]$, bu sebeple sistemin kesikli işletilmesi giderim veriminin artması açısından tavsiye edilmiştir.

Meriç-Ergene Havzası'nda tasarlanacak olan yapay sulak alan sistemlerinde hidrolik yükün kontrolü ve hidrolik bekletme süreleri de pestisitlerin gideriminde önemli parametrelerdir. Serbest yüzey akışlı yapay sulak alanların bu havza üzerinde kurulması en iyi yönetim uygulaması olarak pestisit giderim verimini arttıracaktır. Açık sistemlerde pestisitler üzerinde yapılacak çalışmalarda, pestisitlerin uçuculuk özellikleri değerlendirilmeli ve bu konu hakkında çalışmalar yapılmalıdır. Tasarlanan yapay sulak alan sistemlerine gelen pestisit yükünü azaltmak ve giderim verimini arttırmak amaciyla tarımsal atık suların verildiği drenaj kanallarının bitkilendirilmesi önerilmektedir. Tarımsal drenaj kanallarının geniş sediment yüzeyine sahip olması ve bitkilendirilmiş şerit uygulamaları pestisit yükünü azaltacak, yapay sulak alanlara taşınan tarımsal atık suların arıtılmasında yarar sağlayacaktır.

Bunun dışında, Meriç-Ergene Havzası için organofosfatlı pestisitlerin taşınımı ve akıbetini belirleyen modellerin kurulması, bu modellerin farklı senaryolar altında çalıștırılarak alınacak tedbirlerin belirlenmesi, havzanın ekolojik yapısının ve havzada yaşayan canlıların korunması açısından son derece önemlidir.

\section{Teşekkür}

Bu çalışma, TÜBİTAK 2232 Programı 115C069 numaralı "Organofosfatlı Pestisitlerin Sulak Alanlarda
Biyolojik Ayrışma ve Enzimatik Biyoremediyasyon Yoluyla Giderimi" projesi kapsaminda gerçekleştirilmiştir. Maddi destekleri için ve bu araștırmaya olan katkılarından dolayı TÜBİTAK'a ve çalışmaya destek olan İTÜ-MEMTEK laboratuvarına teşekkür ederiz.

\section{Kaynakça}

[1] Karpuzcu, M. E., Sedlak, D. L., Stringfellow, W. T. 2013. Biotransformation of chlorpyrifos in riparian wetlands in agricultural watersheds: implications for wetland management, Journal of Hazardous Materials 244-245(2013), 111-20.

[2] Pedersen, J. A., Yeager, M. A., Suffet, I. 2006. Organophosphorus insecticides in agricultural and residential runoff: Field observations and implications for total maximum daily load development, Environmental science \& technology 40(7) (2006) 2120-2127.

[3] Vymazal, J., Březinová, T. 2015. The use of constructed wetlands for removal of pesticides from agricultural runoff and drainage: a review, Environment international 75 (2015) 11-20.

[4] Singh, B. K. 2009. Organophosphorus-degrading bacteria: ecology and industrial applications, Nature Reviews Microbiology 7(2) (2009) 156.

[5] Delen, N., Durmuşoğlu, E., Güncan, A., Güngör, N., Turgut, C., Burçak, A. 2005. Türkiye'de Pestisit Kullanimi, Kalinti ve Organizmalarda Duyarlilik Azalişi Sorunlari, Türkiye Ziraat Mühendisliği 6 (2005).

[6] Tiryaki, O., Canhilal, R., Horuz, S. 2010. Tarım ilaçları kullanımı ve riskleri, Erciyes Üniversitesi Fen Bilimleri Enstitüsü Fen Bilimleri Dergisi 26(2) (2010) 154-169.

[7] Karpouzas, D. G., Singh, B. K. 2006. Microbial degradation of organophosphorus xenobiotics: metabolic pathways and molecular basis, Advances in microbial physiology 51 (2006) 119225.

[8] Demirdöğen, B. 2010. Organophosphate pesticide poisonings and the role of serum paraoxonase 1 (PON1) enzyme in organophosphate metabolism, Türk Hijyen ve Deneysel Biyoloji Dergisi 67(2) (2010) 97-112.

[9] Öterler, B. 2009. 3 Tatlı Su Fitoplankton Türünün (Chlorella vulgaris beij. 1890, Scenedesmus quadricauda (turpin) bréb. 1835 ve Cyclotella meneghiniana kütz. 1844) Gelişimi Üzerine 5 Farklı Pestisitin (Azinphos-methyl, Malathion, Parathion-ethyl, Terbufos, Trichlorfon) Toksisitesi, Fen Bilimleri Enstitüsü, Trakya Üniversitesi, Edirne, 2009.

[10] Matamoros, V., Puigagut, J., García, J., Bayona, J. M., 2007. Behavior of selected priority organic pollutants in horizontal subsurface flow 
constructed wetlands: a preliminary screening, Chemosphere 69(9) (2007) 1374-1380.

[11] Gill, S. L., Spurlock, F. C., Goh, K. S., Ganapathy, C. 2008. Vegetated ditches as a management practice in irrigated alfalfa, Environmental monitoring and assessment 144(1-3) (2008) 261-267.

[12] Sherrard, R., Bearr, J., Murray-Gulde, C., Rodgers Jr, J., Shah, Y. 2004. Feasibility of constructed wetlands for removing chlorothalonil and chlorpyrifos from aqueous mixtures, Environmental Pollution 127(3) (2004) 385-394.

[13] Cooper, C., Moore, M., Bennett, E., Smith, S., Farris, J., Milam, C., Shields, F. 2004. Innovative uses of vegetated drainage ditches for reducing agricultural runoff, Water Science and Technology 49(3) 117-123.

[14] Bouldin, J., Farris, J., Moore, M., Cooper, C. 2004. Vegetative and structural characteristics of agricultural drainages in the Mississippi Delta landscapes, Environmental Pollution 132(3) (2004) 403-411.

[15] Schulz, R., Peall, S. K., 2001. Effectiveness of a constructed wetland for retention of nonpointsource pesticide pollution in the Lourens River catchment, South Africa, Environmental science \& technology 35(2) (2001) 422-426.

[16] Moore, M. T., Cooper, C. M., Smith, S., Rodgers, J.H. 2000. Pesticide mitigation capacities of constructed wetlands, In: Proceedings of a Conference on Sustainability of Wetlands and Water Resources, May 23-25, Oxford, Mississippi, eds. Holland, Marjorie M.; Warren, Melvin L.; Stanturf, John A., p. 133-134.

[17] Budd, R., O'Geen, A., Goh, K. S., Bondarenko, S., Gan, J. 2009. Efficacy of constructed wetlands in pesticide removal from tailwaters in the Central Valley, California, Environmental science \& technology 43(8) (2009) 2925-2930.

[18] Gregoire, C., Elsaesser, D., Huguenot, D., Lange, J., Lebeau, T., Merli, A., Mose, R., Passeport, E., Payraudeau, S., Schütz, T. 2009. Mitigation of agricultural nonpoint-source pesticide pollution in artificial wetland ecosystems-a review, Climate Change, Intercropping, Pest Control and Beneficial Microorganisms, Springer2009, pp. 293-338.

[19] Rogers, M. R., Stringfellow, W. T. 2009. Partitioning of chlorpyrifos to soil and plants in vegetated agricultural drainage ditches, Chemosphere 75(1) (2009) 109-114.

[20] Karpuzcu, M. E., Sedlak, D. L., Stringfellow, W. T. 2013. Biotransformation of chlorpyrifos in riparian wetlands in agricultural watersheds: Implications for wetland management, Journal of hazardous materials 244 (2013) 111-120.
[21] Swift, M. C., Niemi, G. J., Perry, J. A. 2015. Predictive Modeling and Experimental Design of Lotic Mesocosms.

[22] Rodgers, J. H., Dunn, A. 1992. Developing design guidelines for constructed wetlands to remove pesticides from agricultural runoff, Ecological Engineering 1(1) (1992) 83-95.

[23] Moore, M., Schulz, R., Cooper, C., Smith, S., Rodgers, J. 2002. Mitigation of chlorpyrifos runoff using constructed wetlands, Chemosphere 46(6) (2002) 827-835.

[24] Moore, M., Rodgers Jr, J., Cooper, C., Smith Jr S. 2000. Constructed wetlands for mitigation of atrazine-associated agricultural runoff, Environmental pollution 110(3) 393-399.

[25] Detenbeck, N. E., Hermanutz, R., Allen, K., Swift, M. C. 1996. Fate and effects of the herbicide atrazine in flow-through wetland mesocosms, Environmental Toxicology and Chemistry 15(6) (1996) 937-946.

[26] Rogers, M. R., Stringfellow, W. T. 2009. Partitioning of chlorpyrifos to soil and plants in vegetated agricultural drainage ditches, Chemosphere 75(1) (2009) 109-14.

[27] Moore, M. T., Kroger, R., Locke, M. A., Lizotte, R. E., Testa, S. 2014. 3rd, C.M. Cooper, Diazinon and permethrin mitigation across a grass-wetland buffer, Bulletin of Environmental Contamination and Toxicology 93(5) (2014) 574-9.

[28] Dabrowski, J.,Peall, S., Reinecke, A., Liess, M., Schulz, R. 2002. Runoff-related pesticide input into the Lourens River, South Africa: basic data for exposure assessment and risk mitigation at the catchment scale, Water, Air, and Soil Pollution 135(1-4) (2002) 265-283.

[29] Cheng, S., Vidakovic-Cifrek, Ž. Grosse, W., Karrenbrock, F. 2002. Xenobiotics removal from polluted water by a multifunctional constructed wetland, Chemosphere 48(4) (2002) 415-418.

[30] Mahabali, S., Spanoghe, P. 2014. Mitigation of two insecticides by wetland plants: feasibility study for the treatment of agricultural runoff in Suriname (South America), Water, Air, \& Soil Pollution 225(1) (2014) 1771.

[31] McKinlay, R., Kasperek, K. 1999. Observations on decontamination of herbicide-polluted water by marsh plant systems, Water research 33(2) (1999) 505-511.

[32] Locke, M., Weaver, R., Zablotowicz, R., Steinriede, R., Bryson, C., Cullum, R. 2011. Constructed wetlands as a component of the agricultural landscape: mitigation of herbicides in simulated runoff from upland drainage areas, Chemosphere 83(11) (2011) 1532-1538.

[33] Stearman, G. K., George, D. B., Carlson, K., Lansford, S. 2003. Pesticide removal from container nursery runoff in constructed wetland 
cells, Journal of environmental quality 32(4) 1548-1556.

[34] Tokatlı, C., Köse, E., Uğurluoğlu, A., Çiçek, A., Emiroğlu, Ö. 2014. Use of Geographic Information System (GIS) to Evaluate the Water Quality of Gala Lake (Edirne), Sigma 32 490-501.

[35] Köse, E. 2015. Meriç Deltası ve civarının florası. .Trakya Üniversitesi, Fen Bilimleri Enstitüsü, Yüksek Lisans Tezi, 59s, Edirne.

[36] Benhabib, K., Town, R. M., van Leeuwen, H. P. 2009. Dynamic speciation analysis of atrazine in aqueous latex nanoparticle dispersions using solid phase microextraction (SPME), Langmuir 25(6) 3381-3386.

[37] Wu, J., Laird, D. A. 2004. Interactions of chlorpyrifos with colloidal materials in aqueous systems, Journal of environmental quality 33(5) 1765-1770.

[38] Goodrich, J.A., Lykins, B.W., Clark, R. M. 1991. Drinking water from agriculturally contaminated groundwater, Journal of Environmental Quality 20(4) (1991) 707-717.

[39] Gerstl, Z. 1990. Estimation of organic chemical sorption by soils, Journal of contaminant hydrology 6(4) (1990) 357-375.

[40] Sabljić, A., Güsten, H., Verhaar, H., Hermens, J. 1995. QSAR modelling of soil sorption. Improvements and systematics of log K OC vs. log K OW correlations, Chemosphere 31(11) (1995) 4489-4514.

[41] Howard, P.H. 1991 Handbook of environmental fate and exposure data: for organic chemicals, volume III pesticides, CRC press, United States, 103 s.
[42] Arienzo, M., Crisanto, T., Sanchez-Martin, M. J., Sanchez-Camazano, M. 1994. Effect of soil characteristics on adsorption and mobility of (14C) diazinon, Journal of Agricultural and Food Chemistry 42(8) (1994) 1803-1808.

[43] Nemeth-Konda, L., Füleky, G., Morovjan, G., Csokan, P. 2002. Sorption behaviour of acetochlor, atrazine, carbendazim, diazinon, imidacloprid and isoproturon on Hungarian agricultural soil, Chemosphere 48(5) 545-552.

[44] Hernández-Soriano, M. C., Peña, A., Mingorance, M. D. 2007. Retention of organophosphorous insecticides on a calcareous soil modified by organic amendments and a surfactant, Science of the total environment 378(1) (2007) 109-113.

[45] Liu, B., McConnell, L., Torrents, A. 2001. Hydrolysis of chlorpyrifos in natural waters of the Chesapeake Bay, Chemosphere 44(6) (2001) 1315-1323.

[46] Karpuzcu, M. E. 2012. Wetlands as Best Management Practices to Mitigate Agricultural Nonpoint Source Pollution, Civil and Environmental Engineering UC Berkeley, UC Berkeley, California, 2012.

[47] Walker, W., Cripe, C., Pritchard, P., Bourquin, A. 1988. Biological and abiotic degradation of xenobiotic compounds in in vitro estaurine water and sediment/water systems, Chemosphere 17(12) (1988) 2255-2270.

[48] Bondarenko, S., Gan, J. 2004. Degradation and sorption of selected organophosphate and carbamate insecticides in urban stream sediments, Environmental Toxicology and Chemistry 23(8) (2004) 1809-1814. 